\title{
TITLE:
}

\section{Characterization of a free arrangement and conjecture of Edelman and Reiner(Abstract_要旨 )}

AUTHOR(S):

Yoshinaga, Masahiko

\section{CITATION:}

Yoshinaga, Masahiko. Characterization of a free arrangement and conjecture of Edelman and Reiner. 京都大学, 2004, 博士(理学)

ISSUE DATE:

2004-05-24

URL:

http://hdl.handle.net/2433/145466

RIGHT: 
氏 名 吉 $\begin{array}{lll}\text { 永 } & \text { 正 } & \text { 彦 }\end{array}$

学位(専攻分野) 博 士 (理 学)

学位記番号理 博 第 2835 号

学位授与の日付平 成 16 年 5 月 24 日

学位授与の要件 学 位 規則第 4 条第 1 項該 当

研究科. 専攻 理学研究科数学. 数理解析専攻

学位論文題目 Characterization of a free arrangement and conjecture of Edelman and Reiner.

（自由配置の特徵付けと Edelman-Reiner の予想）

論文調査委員 教 授 齋 藤 恭司教 授柏 原正樹教 授向井茂

論文内容 の 要旨

本論文は，組み合わせ論に於ける超平面配置に関する Edelman-Reiner 予想に完全な解答を与えるものである。

超平面配置とは有限次元の複素又は実べクトル空間とそれに含まれる有限個の超平面の族の組の事である。与えられた超 平面配置にたいしべクトル空間上の多項式を係数とするべクトル場で配置超平面族にその生成点に於て接するものを対数べ クトル場とよぶ。それら全体のなす加群は空間の係数環上の加群として反射層になるが, 特に自由加群になるとき，その超 平面配置を自由と呼ぶ。自由配置の理論は齋藤の創始によるものでその自由性の判定法が知られている。自由配置はその補 集合が著しい位相的特徵を示すことから注目され，組み合わせ論的立場から多くの研究がなされて来た。例えば寺尾により 「配置平面の補集合のポアンカレ多項式は有理一次因数に分解しその分解係数は対数ベクトル場のなす自由加群基底の次数 (巾指数と呼ばれる) で与えられる」が知られている。この様に自由配置の研究は現在も活発に進展中である。特にアファ インルート系との関連で1997に提出されたEdelman-Reinerによる予想，及び Stainlay 等による“リーマン予想”はその 専門家多くの関心をあつめ, 超平面配置の組み合わせ論の一つの中心的課題として研究されてきている。

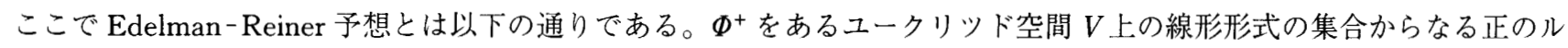
一ト系とし，その巾指数を $\left(e_{1}, \cdots, e_{\ell}\right)$ とする。整数 $k$ とルート $\alpha$ にたいし $V$ 超平面 $H_{\alpha, k}:=\{x \in V \mid \alpha(x)=k\}$ 及びそれ らからなる配置 $A_{\Phi}^{[p, q]}:\left\{H_{\alpha, k} \mid \alpha \in \Phi^{+}, k \in Z, p \leq k \leq q\right\}$ を考える(但し, $p, q(p \leq q)$ は整数)。いま $m$ を任意の非負整数, $h$ をコクセタ数とする。この時, $A_{\Phi}^{[-m, m]}$ の錘は $\left(1, e_{1}+m h, \cdots, e_{\ell}+m h\right)$ を巾指数とする自由配置であり, $A_{\Phi}^{[1-m, m]}$ の錘流 $(1$, $m h, \cdots, m h)$ を巾指数とする自由配置である。

本論文に於て申請者は代数幾何学的視点から自由性の新たな特徴付けを与え, その応用として上記の Edelman-Reiner 予想を含む一連の超平面配置の自由性の証明を与えた。

自由性の新たな判定は本来大域的に定義されていた概念を層化することにより射影空間上のべクトル束という代数幾何的 な対称に置き換えることによりなされる。即ち，対数べクトル場加群が自由であるとはベクトル空間に付随する射影空間上 の層として直線束の直和に分解することと同值である。この事をふまえて申請論文に於てつぎの自由性の判定法が証明され ている:

$l+1$ 次元空間上に超平面配置 $A$ が与えられたとする（但し $l \geq 3 ） 。 A$ 中の超平面 $H$ を一つ選んで㧍く。この時 $A$ が巾指数 を $\left(1, e_{1}, \cdots, e_{\ell}\right)$ とする自由配置になる事は次の二条件と同值である。

i ) $A$ と $H$ の交叉で定まる $H$ 上の重複配置は $\left(e_{1}, \cdots, e_{\ell}\right)$ を巾指数とする自由配置である。

ii）原点以外の $H$ 上の各点に於て $A$ は自由である。

この定理の証明にはべクトル束の場合に知られていたコホモロジーの消滅に関する議論が巧妙に用いられる。この判定法 により $A$ の自由性は次元に関する帰納法が適用可能となるのである。 


\section{論 文 審 查 の 結 果 の 要 旨}

自由配置の理論は, 元来余次元 1 のディスクリミナント集合を持つパラメタ空間上のガウス - マニン接続の研究のために 生まれた。その為その研究の当初よりディスクリミナントの補集合の位相との関連が研究の関心の中心にあった。即ち補集 合は $K(\pi, 1)$ - 空間になるか否か, そのコホモロジー環の構造について, ポアンカレ多項式の分解について, 基本群の構 造等などが問題となり，それらの問題の幾つかは肯定的又は否定的に解決された。また当初研究されたルート系に対応する コクセタ配置のみならず多様かつ組み合せ論的に重要な例が生まれ, 自由配置の研究はそれ自体が超平面配置の理論の中で 独立した研究対象として組み合わせ論の一分野を形成するに至った。

そのなかで, Edelman-Reiner 予想はそれ以前に研究されたCatalan 配置やShi 配置に関する予想を統合一般化するひと つの中心的課題として関係する多くの研究者の注目を集め，ここ数年にわたり関連する部分的結果が発表されてきた。申請 論文はそれら断片的な結果を越えて同予想に完全な解決を与えている。その仕事は超平面配置の理論に顕著な貢献を与える ものであり，当該分野から非常に高い評価を得ている。

主結果は，一般の超平面配置の自由性の新たな帰納的な判定法を与えるという一般性の高いものであり，当初の Edelman-Reiner 予想のみならず更なる応用も期待され今後の同方面発展方向を一つ示したものとして高く評価できる。また用 いられた方法も従来主に用いられた組み合わせ論的な方法に代数幾何的方法も加え，方法的にも元来の研究課題であったホ ッジ構造との関連が視野に入るなど当該分野に更なる発展をうながすことを期待させるものである。

主論文のみならず, 参考論文 $1 「 T$ The primitive derivation and freeness of multi-Coxeter arrangements」においては, 主論文の主定理を適用するに際して必要な多重配置の自由性の判定条件を深く研究しており申請者の重要な貢献となってい る。参考論文 $2 「$ On the freeness of 3-arrangements」においては主論文では扱えない3次元空間上の配置についてその 自由性の判定を特性多項式及び多重配置の自由性に還元するという非常に興味深い結果を与えておりそれ自体価値あるもの であるのみならず，申請者の当該分野全体への深い理解と洞察力をしめしている。

申請者は大学院在学 5 年末満であり, 特例を適用するに充分であるかどうかを慎重に審査をおこなった。その結果, 以上 のような理由により，本論文は博士（理学）の学位論文として充分なものと考える。論文内容とそれに関連した口頭試問を 行なった結果合格と認めた。 